XIV Российская национальная конференция по сейсмостойкому строительству и сейсмическому районированию (с международным участием). Сборник материалов

УДК 699.81

DOI 10.37153/2687-0045-2021-14-69-73

\title{
ОПЫТ СЕРТИФИКАЦИИ И СЕРТИФИКАЦИОННЫХ ИСПЫТАНИЙ ОБОРУДОВАНИЯ, ИЗДЕЛИЙ И КОНСТРУКЦИЙ С УЧЕТОМ ПОЖАРНОЙ СЕЙСМОСТОЙКОСТИ
}

Ладыгина И.Р., Заместитель руководителя Научно-экспертного бюро пожарной, экологической безопасности в строительстве ЦНИИСК им. В.А. Кучеренко АО «НИЦ

«Строительство»

Требования Федерального закона от 30.12.2009 № 384-Ф3

«Технический регламент о безопасности зданий и сооружений»

\section{Статья 3. Сфера применения настоящего Федерального закона}

Настоящий Федеральный закон устанавливает минимально необходимые требования к зданиям и сооружениям (в том числе к входящим в их состав сетям инженерно-технического обеспечения и системам инженерно-технического обеспечения), а также к связанным со зданиями и с сооружениями процессам проектирования (включая изыскания), строительства, монтажа, наладки, эксплуатации и утилизации (сноса), в том числе требования:

1) механической безопасности;

2) пожарной безопасности;

3) безопасности при опасных природных процессах и явлениях и (или) техногенных воздействиях;

4) безопасных для здоровья человека условий проживания и пребывания в зданиях и сооружениях;

5) безопасности для пользователей зданиями и сооружениями;

6) доступности зданий и сооружений для инвалидов и других групп населения с ограниченными возможностями передвижения;

7) энергетической эффективности зданий и сооружений;

8 ) безопасного уровня воздействия зданий и сооружений на окружающую среду.

Обязательные требования к объектам технического регулирования. Дифференцированный подход к вопросам подтверждения соответствия

Федеральный закон от 22.07.2008 № 123-Ф3 «Технический регламент о требованиях пожарной безопасности»

СП 2.13130.2020 «Системы противопожарной защиты. Обеспечение огнестойкости объектов защиты»

СП 4.13130.2013 «Ограничение распространения пожара на объектах защиты»......

Заключения по огнестойкости $и$ пожарной опасности строительных конструкций:

ГОСТ 30247.1-94 «Конструкичии строительные. Методы испытаний на огнестойкость. Несущие и ограждающие конструкиии»

ГОСТ 30403-2012 «Конструкции строительные. Метод испытаний на пожарную опасность» 
XIV Российская национальная конференция по сейсмостойкому строительству и сейсмическому районированию (с международным участием). Сборник материалов

ГОСТ 31251-2008 «Стены наружные с внешней стороны. Метод испытаний на пожарную опасность»

ГОСТ Р 53309-2009 «Здания и фрагменты зданий. Метод натурных огневых испьтаний. Общие требования»....

\section{СП 14.13330.2018 «Строительство в сейсмических районах»}

Заключения по сейсмостойкости строительных конструкций:

ГОСТ 30546.2-98 «Испытания на сейсмостойкость машин, приборов и других технических изделий. Общие положения и методы испьтаний»

СТО 36554501-016-009 «Строчтельство в сейсмических районах. Нормь проектирования зданий»...

\section{СП 28.13330.2017 «Защита строительных конструкций от коррозии»}

Заключения по срокам службы спечиальных покрытий:

ГОСТ ISO 9223-2017 «Коррозия металлов и сплавов. Коррозионная активность атмосферы. Классификаџия, определения и оценка»

ГОСТ 9.401-2018 «Единая система защиты от коррозии и старения (ЕСЗКС). Покрытия лакокрасочные. Общие требования и методы ускоренных испытаний на стойкость к воздействию климатических факторов»...

\section{Нарушения структурной целостности строительных конструкций после механических и климатических воздействий}

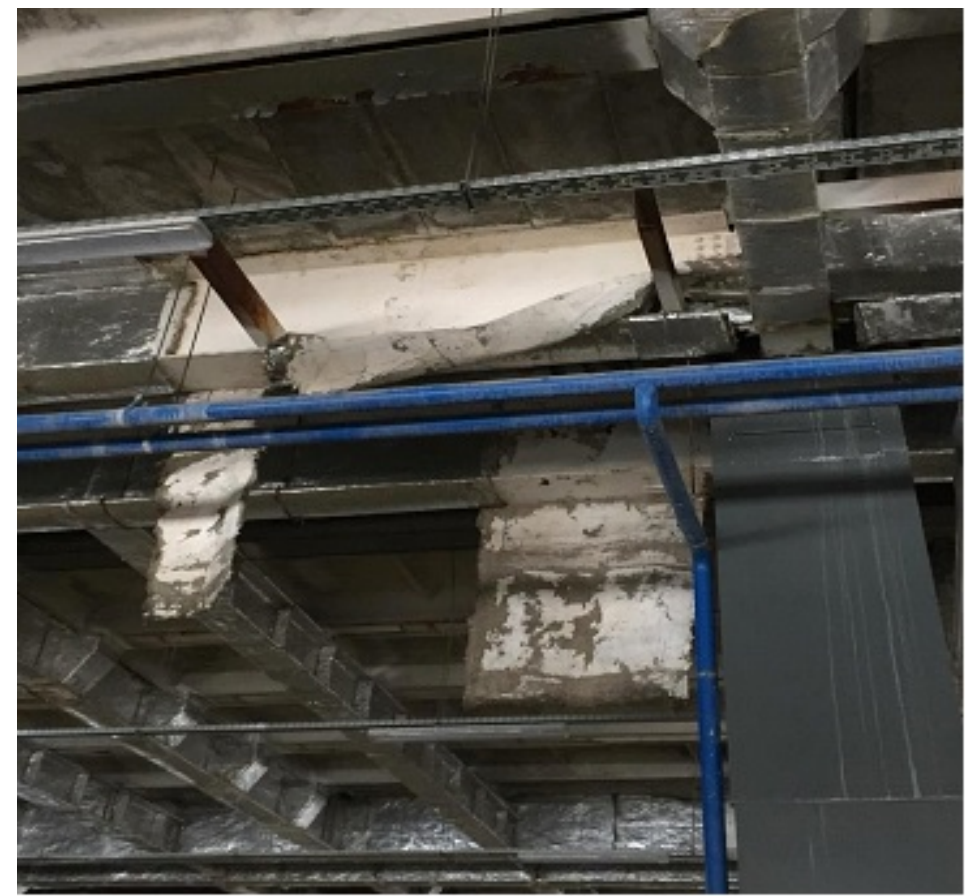


XIV Российская национальная конференция по сейсмостойкому строительству и сейсмическому районированию (с международным участием). Сборник материалов

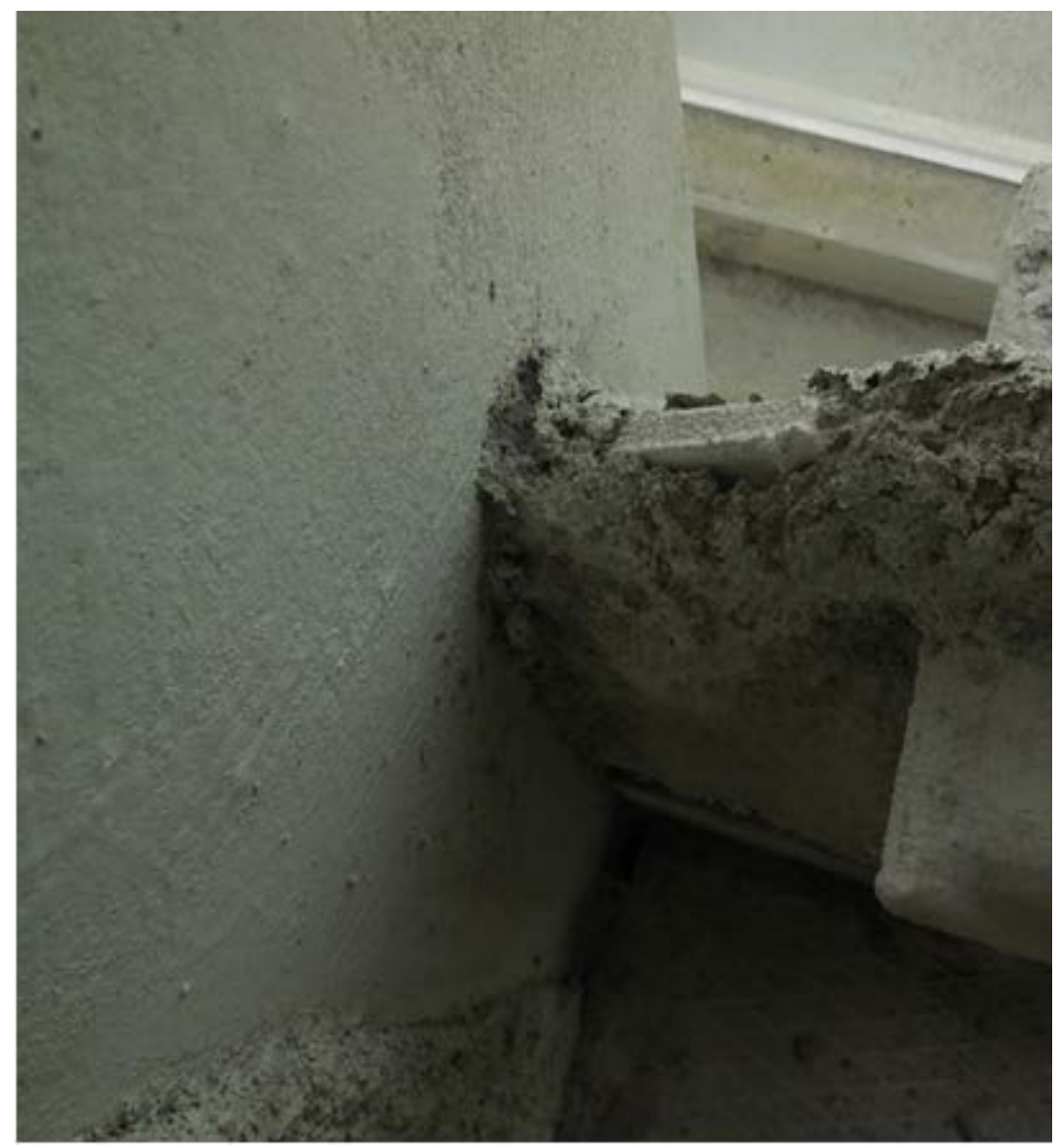

Интегрированные методы испытаний объектов защиты на сейсмостойкость и огнестойкость 
XIV P

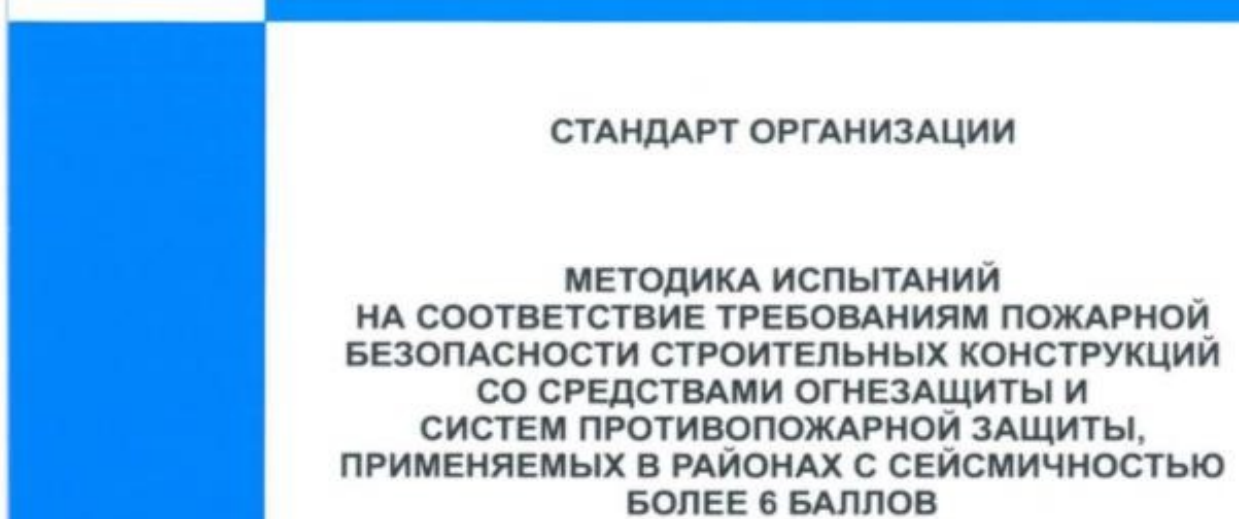

НА СООТВЕТСТВИЕ ТРЕБОВАНИЯМ ПОЖАРНОЙ

БЕЗОПАСНОСТИ СТРОИТЕЛЬНЫХ КОНСТРУКЦИИ

ПРИМЕНЯЕМЫХ В РАЙОНАХ С СЕЙСМИЧНОСТЬЮ БОЛЕЕ 6 БАЛЛОВ

сто 36554501-031-2013

- Определение оптимальных габаритных размеров образцов для испытаний, с учётом требований сейсмостойкости и огнестойкости

- Разработка программы сейсмических воздействий на образцы строительных конструкций с учётом реальных условий эксплуатации

- Разработка программы огневого воздействия на образцы с учётом расчётного сценария пожара

- Определение требований к испытательным установкам и средствам измерений

- Анализ допустимого снижения огнестойкости после сейсмических воздействий

\section{Система добровольной сертификации «СейсмПБ»}

При применении Знака СДС «СейсмПБ» его изображение должно быть четко отличимым от поверхности официальных бланков, вывесок, печатных изданий в рекламе и т.д.

Знак СДС «СейсмПБ» наносят полностью согласно его изображению. Не допускается наносить отдельные элементы его изображения.

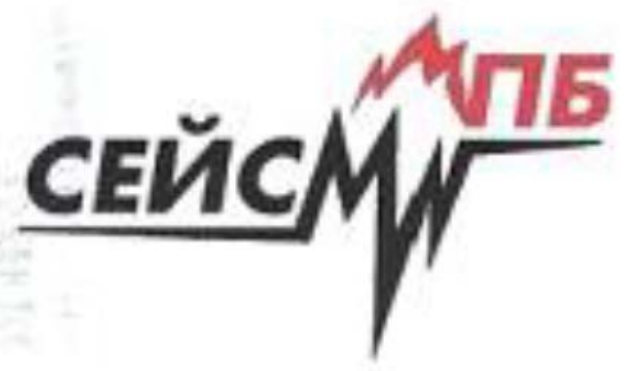


XIV Российская национальная конференция по сейсмостойкому строительству и сейсмическому районированию (с международным участием). Сборник материалов

Размеры и место нанесения Знака СДС «СейсмПБ» определяет заявитель.

Размеры Знака СДС «СейемПБ» должны гарантировать четкость и различимость его элементов невооруженным глазом.

Маркирование Знаком СДС «СейсмПБ» производится, как правило, на свободном поле и может осуществляться следующим технологическим приемом: нанесение плоского или рельефного изображения Знака СДС «СейсмПБ» на официальные бланки, вывески, печатные издания и в рекламе и т. д. в холе технологического процесса их изготовления с помощью специализированной технологической оснастки.

Знак «СейсмПБ» выполняют различными технологическими способами, обеспечивающими его четкое и ясное изображение в течение всего срока службы изделия. Для изображения знака «СейсмПБ» применяется черный и красный цвет с цветографическими характеристиками по ГОСТ 12.4.026. В случае, при котором технологический способ нанесения знака «СейсмПБ» на изделие не предусматривает применения черного и красного цвета, необходимо обеспечить четкое и ясное изображение знака «СейсмПБ» другим технологическим методом.

Знаком «СейсмПБ» маркируется каждое изделие, его тара (упаковка) и техническая документация, прилагаемая к каждой единице продукции.

Местонахождение знака «СейсмПБ»-рядом с товарным знаком изготовителя, а при его отсутствии рядом с основной маркировкой (для изделий и тары) и в верхней части первого листа технической документации (для технической документации).

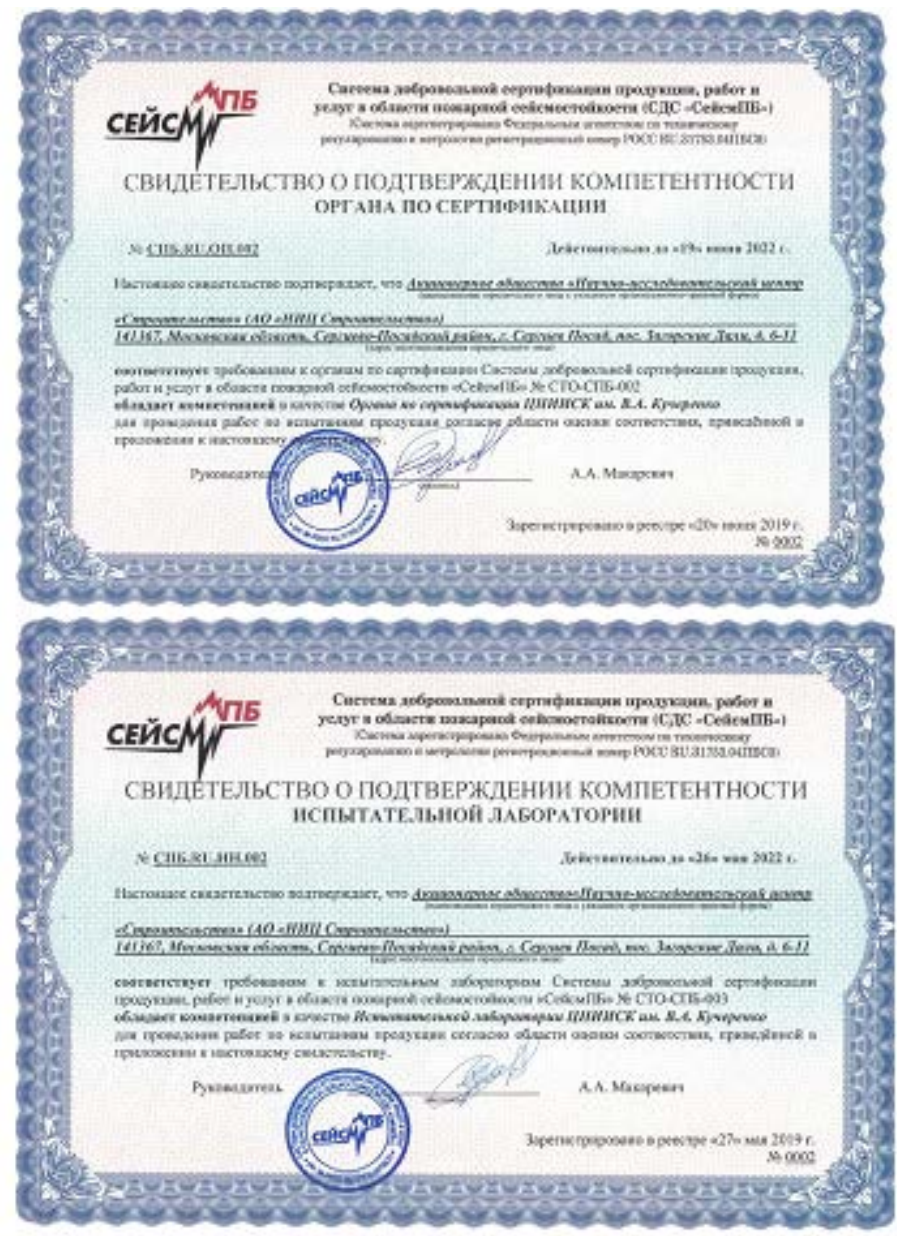

